\title{
Patiëntenvoorlichting PV 30 Cheilitis actinica
}

Cheilitis actinica is een door zonlicht veroorzaakte ontstekingsachtige afwijking van de lippen. Meestal betreft het de onderlip. De afwijking komt vooral bij mannen voor. Vaak betreft het oudere mannen, die beroepshalve veel in de buitenlucht werken of hebben gewerkt.

Cheilitis actinica uit zich als een soms pijnlijke, korstvormende verandering van het lippenrood. Een enkele maal blijkt zich onder de korstvorming een kankerplekje te hebben ontwikkeld. Om die reden wordt in sommige gevallen een weefselstukje uit de laesie verwijderd voor onderzoek door de patholoog. Afhankelijk van de grootte van de afwijking en het al of niet aanwezig zijn van klachten, kan worden volstaan met controle, bij voorbeeld halfjaarlijks. Het is belangrijk om blootstelling aan zonlicht zoveel mogelijk te vermijden en in ieder geval de lip te beschermen met bij voorbeeld cacaoboter. Door sommige huidartsen wordt bij de behandeling van cheilitis actinica gebruikgemaakt van een etsende vloeistof of van bevriezing. Vaak echter wordt overgegaan tot een oppervlakkige chirurgische verwijdering ("lipshave"). Meestal kan deze verwijdering onder plaatselijke verdoving worden uitgevoerd. Het voordeel van chirurgische verwijdering is, dat het verwijderde weefsel door de patholoog kan worden gecontroleerd.

\section{Wat kunt u zelf doen?}

U kunt bij het vermoeden op aanwezigheid van cheilitis actinica zelf niet zo veel doen, anders dan overmatige blootstelling aan zonlicht te vermijden en in ieder geval de lip te beschermen.
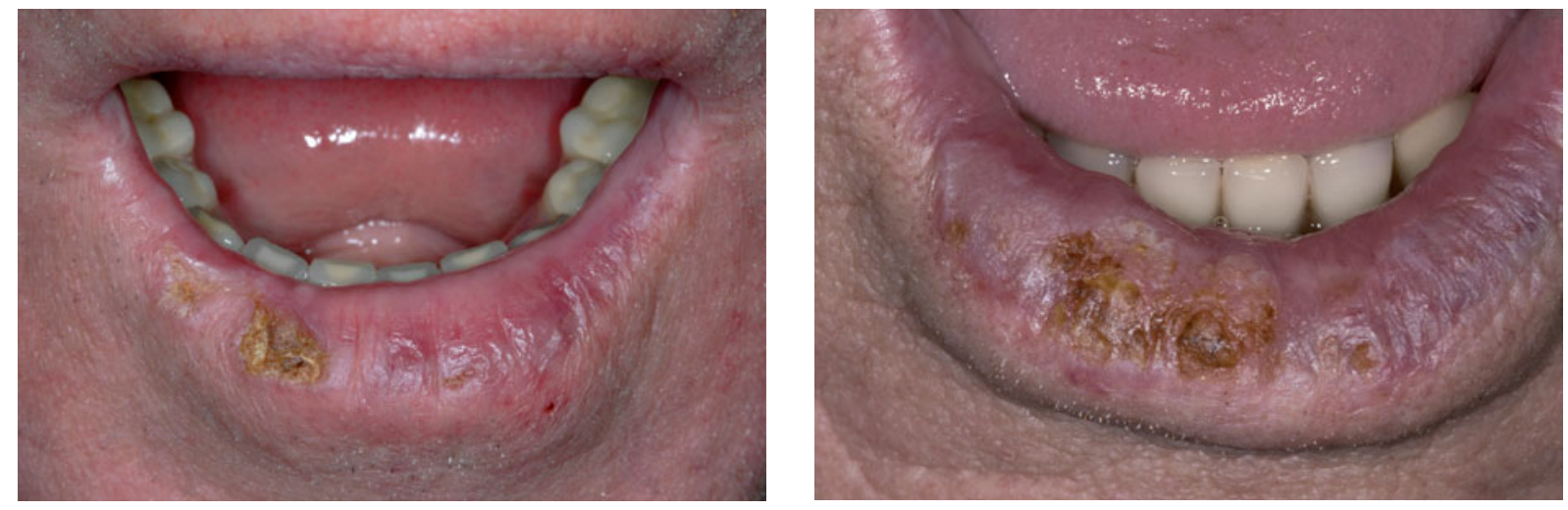